\title{
Are we hearing the voices? Africanisation as part of community development
}

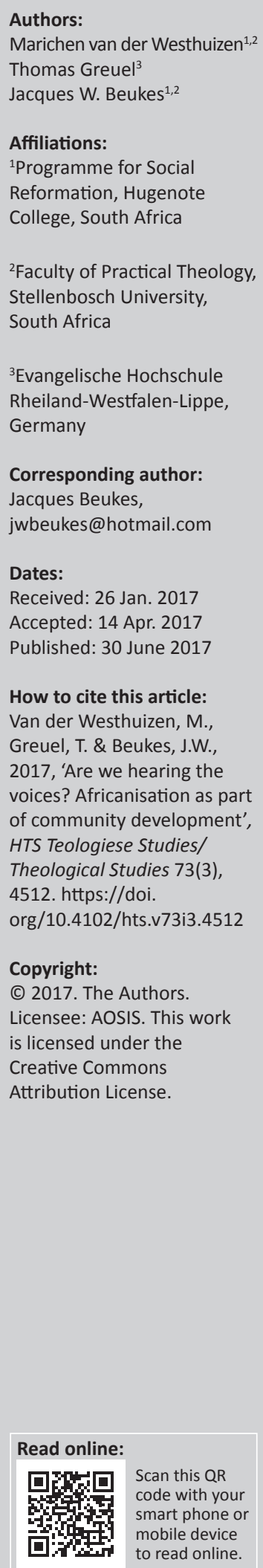

\begin{abstract}
The aim of the article is to report on research findings that could contribute to the development of decolonised academic material. Africanisation of curricula implies that education and training as well as praxis be informed by the reality of the South African context, the viewpoints of the people of South Africa and their descriptions of what is needed to build a just society. This is relevant to a variety of service professions. This article was presented from a transdisciplinary framework, and the term 'professional carers', including the social service and theology professions, was used. The discussion explored how academia can approach the development of curricula that will inform praxis and which is relevant to the African context. The terms 'Africanisation', 'decolonisation' and 'contextualisation' were linked, whereafter a developmental approach to the development of the content and presentation of academic material was proposed. The article is concluded with recommended strategic options for the development of Africanised curricula.
\end{abstract}

\section{Introduction}

Looking back on the socio-economic and political movements in South Africa 22 years into democracy, various changes can be identified. For example, post-Apartheid policy documents clearly indicate the inclusion of social development as the approach to ensure that the diverse South African people are empowered and included in processes that are aimed at improving the lives of all citizens in a socially just manner. Empowerment manifests through participation, collaboration and cooperation (Geoghegan \& Powell 2006:845). Community development may be viewed as a method of implementing social development, as it assists the state to move from a 'needs satisfying' to a 'facilitating' state where citizens themselves become involved in their futures (Hart 2012:55-56). The caring professions (i.e. social service professions and theology) are viewed as main role players in facilitating this development of communities. ${ }^{1}$

The research that informed this study focused on subgroups within a specific community in an effort to identify practical ways to engage them in a process where members of different subgroups start to work together towards a common goal. Community development is aimed at the macro level of functioning and characterised by the fact that the community is seen as a system within a specific geographical area that consists of interdependent subsystems. Our study focused on one community and some of its subsystems as part of an exploration of a possible process and techniques to follow to ensure that the subsystems join hands in order to work together for the 'common good' (i.e. participation and cooperation), with networking and collaboration as key factors to success (Weyers 2011:154-155). It was envisaged that the outcomes of this research could further be explored within the academic field.

Despite the guidelines obtained from theoretical descriptions of what community development principles and practices entail, a heeding call from both staff and students at universities and academic colleges as well as practitioners points to the fact that we need to reconsider how '... education presents a decolonised curriculum' (ASASWEI 2016:1). Prinsloo (2016:164) asserts that the South African people are still not being heard when societal issues come to the fore. For example, the current \#FeesMustFall movement at local universities illustrates how dealing with voiced concerns from grassroots level did not include a collaborative and participative process, whereby students were involved in finding solutions. Prinsloo (2016) recommends that:

... deep understanding of these questions are necessary to prevent more of the same 'techno-bureaucratic fixes', which, until now, have left South Africa's universities largely untransformed. (p. 164)

1.See also August (1999), Beukes (2016), Botman (2004), De Gruchy (2003), De Gruchy and Ellis (2008), Koegelenberg (1992), Le Bruyns and Pauw (2004), Nürnberger (1994) and Swart (2006) for a detailed discussion on why the church and theology are key role players in community development. 
We argue that, in order for sustainable human development to take place, education and training in South Africa should be based on the realities of the African contexts in which our service beneficiaries are functioning. Therefore, we need to explore how we can ensure that we develop curricula that will empower students, include them in exploring solutions for societal problems (i.e. participation, collaboration and cooperation) and guide them to become effective facilitators of community development where beneficiaries participate in decision-making processes that affect their lives. In line with this argument, this article was informed by three research studies that engaged students in the fields of social services and theology in a hermeneutical process to encourage awareness and tolerance in a diverse society (Van der Westhuizen \& Greuel 2016:2-3).

The discussion that follows is based on the following problem statement: We acknowledged that social development directs the approach of the caring professions, as it is emphasised in legislative and policy documents. Community development supports this approach in that it focuses on the empowerment of people to work together through principles of participation, cooperation and collaboration. These principles should therefore inform academic material for the caring professions, not only through knowledge but through skills to encourage the practice of these principles in our communities. Despite our academic understanding and vast descriptions of community development and research available that reports on the needs of South African people, current social actions point to the fact that these principles were not implemented in practice, again pointing to a need to include this in academic material. The trans-disciplinary approach assisted us to, from different theoretical angles and by including grassroots input, identify strategies that encourage empowerment by means of the active implementation of the said principles.

This discussion firstly places the focus on a trans-disciplinary approach in the professional caring disciplines to contribute to decolonised / Africanised academic content, whereafter the link between the terms 'Africanisation', 'decolonisation' and 'contextualisation' will be reflected on. The development of communities as part of Africanisation will be discussed, while strategic options on how community development can become a guiding principle of the development and implementation of Africanised curricula will be explored as a conclusion to the discussion.

\section{A trans-disciplinary approach}

Three disciplines were included in the trans-disciplinary discourse and work, namely social work, the arts (music, dance and photography) and theology. While social work and theology are both disciplines aimed at improving the quality of lives of, and interactions between people (cf. George 2012:17; Thesnaar 2012:4; Van der Westhuizen \& Kleintjes 2015:120), the arts provides the caring professions with a creative tool to create awareness and to promote communication between individuals, groups and communities in a non-threatening manner (Kinnunen \& Kaminski 2003:7).
Trans-disciplinary work refers to a concerted effort between disciplines that creates a movement across the disciplines and results in a product beyond all disciplines (Nicolescu 2005:23). Our effort to work from a trans-disciplinary approach was aimed at contributing to the development of Africanised academic content that informs praxis and thereby contributing to decolonisation and community development.

Typical of the trans-disciplinary approach, all disciplines involved in a specific field work together and learn from each other to assess (i.e. conduct research on grassroots level) and to develop services and products. A key component is that it also involves the voices of the recipients of such services. It is therefore not limited to an academic discourse (Stock \& Burton 2011:1090). In this regard, South African policies acknowledge the inclusion of recipients by means of the social development approach to community well-being. However, considering the ongoing social issues of intolerance, violence, poverty and so forth, we argue that the implementation of principles such as participation, collaboration and cooperation should be critically reviewed. The trans-disciplinary approach therefore places the focus on a bottom-up approach when developing curricula content, which should impact on service delivery. Additionally, all those involved in the trans-disciplinary team must be willing to share knowledge and skills (i.e. teaching each other) and to learn from other disciplines to develop a unique understanding of the context. As a result, the different members of the team become able to use knowledge and skills from another discipline, while integrating this with the knowledge and skills from their own discipline (Stock \& Burton 2011:1098). Throughout this learning process between, across and beyond the disciplines, the voices of the people on grassroots level are incorporated in the development of a new understanding. Nissani (1995:121) explains that distinctive components of two or more disciplines are being integrated into '... a single mind'. In this way, we develop a unique and integrated way of developing knowledge, understanding and skills. This integration requires a move from a discipline towards multi- and interdisciplinary work that results in a trans-disciplinary process, as depicted in Figure 1.

In addition to sharing existing knowledge and skills between the disciplines, the single-mindedness of the transdisciplinary approach also moves towards obtaining new knowledge, understanding and skills that reflects multiple viewpoints. With a specific focus on working towards Africanising academic material, the trans-disciplinary team work together to develop a new knowledge and skills base to address context-related socio-economic realities.

The discussion in this article is based on the Transdimensional Knowledge Management Theoretical Model that was developed as the result of research on African knowledge systems. In line with this model, we argue that, in order to contribute to the development of South African communities, education and training of professional carers 


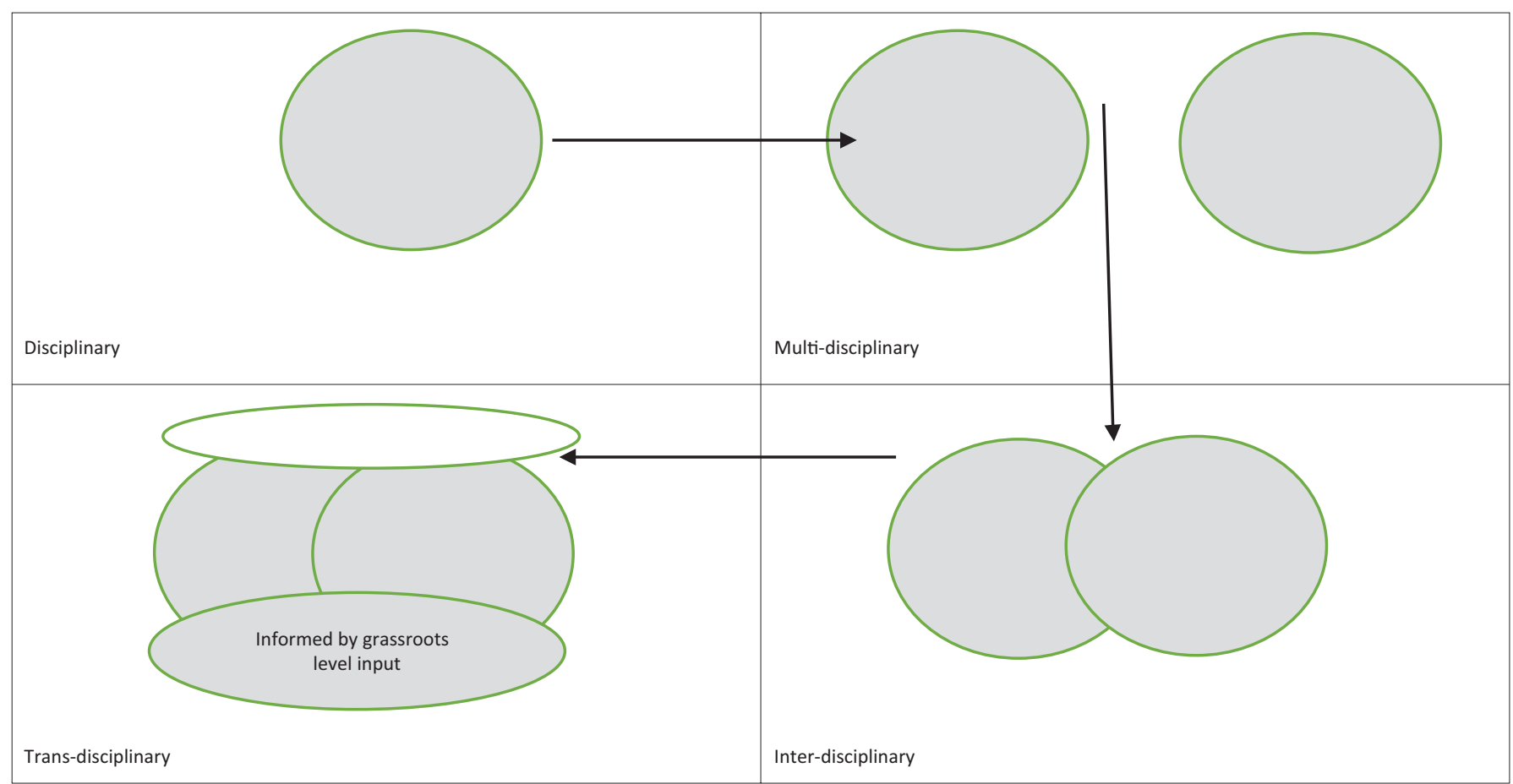

FIGURE 1: A move from disciplinary towards trans-disciplinary work.

should involve a discourse and research projects that result in an organised participatory process where a collective middle ground is identified. Velthuizen (2012) describes the implementation of this model as:

... ensuring credible intra-action to add value to decisions and intervention actions ..., through the application of holistic knowledge production and distribution, focusing on mutual learning. (p. 52)

In the following section, Africanisation and contextualisation as key components of the decolonisation of education and training will be discussed from a trans-disciplinary point of view.

\section{Decolonising through Africanising and contextualising}

In line with the discussion in the previous section, the use of a trans-disciplinary approach to decolonised pedagogy in the caring professions is supported by Razack (2009:9), who argues that different theories and understandings from a variety of disciplines should be compared with each other as also the manner in which they relate to the context. Transdisciplinary discussions therefore work towards unmasking those aspects that prevent Africanised knowledge and skills from developing, as well as towards the exploration of indigenous knowledge and skills to build an empirically sound framework from which to develop academic material.

In this article, we argue that decolonisation of academic material in the caring professions should be aimed at preparing and empowering professional carers to facilitate positive change in communities instead of top-down decision making and implementation. Therefore, indigenous knowledge should be developed to ensure that education and training relate to the African context, which implies that we become informed by grassroots bottom-up research findings. Figure 2 illustrates the outcomes of our trans-disciplinary work and how the concepts of decolonising, Africanising and contextualising relate to each other and how community development informs academic work on the one hand and becomes a result of academic work (i.e. praxis) on the other hand.

The current focus of academic discussions by a variety of disciplines on decolonisation of academic material and praxis may be viewed as a response to four main historical events in South Africa, namely: (1) The years following the arrival of the first Europeans in the Cape (1652 onwards), (2) the years under British Rule (after 1806), (3) the years under Apartheid rule (from 1948) (ASASWEI 2016:1) and (4) the post-Apartheid era (from 1994). The colonised eras resulted in a serious marginalisation of African ways of being, knowing and doing, with the consequence that the minds of African people were colonised, even after the end of Apartheid (ASASWEI 2016:2-3). The latter period can therefore not be ignored, as the influences of the first three eras still linger on.

Decolonisation requires that we actively engage with processes based on a desire to reclaim and revalue the African socio-economic heritage or culture (ASASWEI 2016:3). The present focus on decolonisation in academic discourses could be seen as a reflection on a need to, more than two decades after the end of Apartheid, move beyond the colonised eras to an era where indigenous voices determine future praxis. It should be noted that, if we intend 


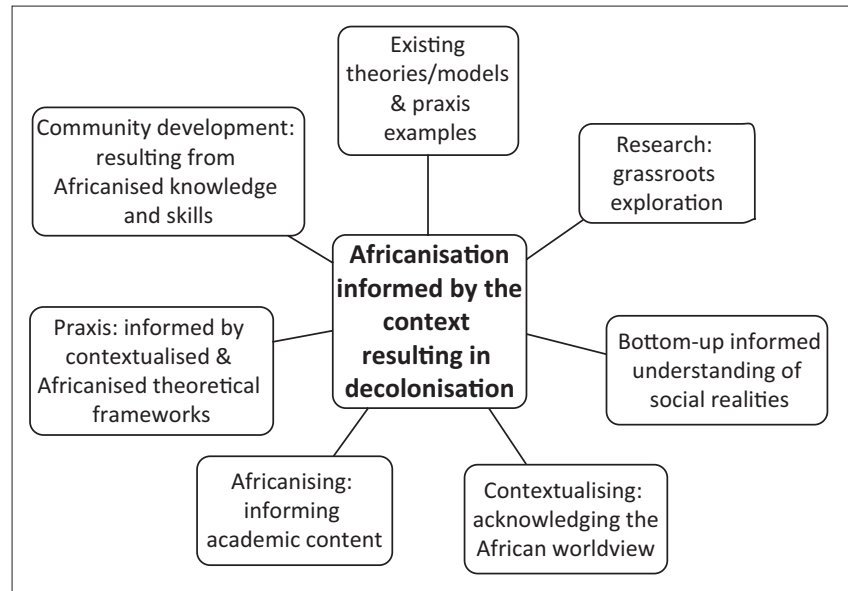

FIGURE 2: A bottom-up approach to Africanised and informed praxis.

to decolonise and to acknowledge indigenous knowledge systems (i.e. the African praxis and ways of doing, knowing and being), we must be informed by the South African people and utilise this information when developing academic curricula and material with the aim to inform praxis. It requires a bottom-up approach where grassroots information is not only being acknowledged but also used to inform the development of a decolonised curriculum that will affect the praxis of caring professions.

The use of indigenous knowledge systems is one way of understanding the term 'Africanisation', as it implies that we move towards an understanding of the African context and the socio-economic realities of the African people. Considering the diversity of the African context, Africanisation implies that we base our efforts to obtain new insights and to develop new praxis on the contextual realities of the beneficiaries of services within a specific context (in the case of this article, South Africa). It requires that we develop criteria that are context related. From a trans-disciplinary approach, it is assumed that we utilise current knowledge bases and praxis (often representing a Western perspective) and explore how (or if) it relates to the African context. This should be seen as cooperative.

In terms of decolonising education and training, we must reflect on whether our teachings relate to the African worldview, which informs how African people deal with phenomena and challenges. Curricula should therefore prepare students to engage with people from an African perspective. Razack (2009:9) proposes that we critically reflect on how we integrate global knowledge (e.g. Westernised information) and indigenous knowledge, understanding and skills. In line with this viewpoint, Thabede (2008:234) explains that an African worldview reflects the '... African cultural beliefs, praxis and values'. This does not mean that we should only focus on developing new decolonised theories and methods, but that we should effectively include the African worldview in existing knowledge when preparing students for praxis. It involves a multicultural curriculum that encourages insight and understanding of our context (Thabede 2008:233-245).
Within the education and training system, the caring professions should firstly assist students to engage in and to facilitate processes where local indigenous praxis and knowledge are linked with existing academic knowledge. Secondly, in the multicultural South African context, the link between different indigenous praxis and knowledge should be explored. The latter is aimed at discovering what '... we have in common with other South African indigenous praxis and knowledge, and indeed with all other Africans', referring to the unity of African culture (ASASWEI 2016:3; Thabede 2008:237).

The Africanisation of our knowledge and skills serves as a stimulus to create transformation towards a decolonised society. Through a trans-disciplinary approach, we need to ensure that we 'hear the relevant voices' and that we become sensitive towards the deeper meaning of the impact of ignoring the plights of people living in the realities of presentday contexts. Tamburro (2013:3) refers to multigenerational trauma because of colonisation. The colonisation of the mind, meaning a lack of self-worth based on not being heard, that lingers on after the end of Apartheid can be addressed when we start to not only hear the perspectives, experiences and needs of the people but when we start to act on these expressions, showing that the viewpoints of those on grassroots level matter. This then becomes the foundation for sustainable transformation. Le Grange (2014:1287-1288) refers to 'the active force of Currere' (Latin for 'to run'), which entails that the education and training of professional carers should involve the capacity '... to run and to create flows, offshoots and a variety of movements', depending on the context.

We included the term 'contextualising' as an action to achieve Africanisation. This requires specific skills to ensure that we base the process towards Africanised and decolonised academic knowledge and skills on contextual information. We therefore have to explore answers to epistemological questions to examine the theories of knowledge and ways of knowing. Abdi (2006:16) explains that we have to revisit what we know, how we know it and what we need to know in order to '... develop diverse trajectories of knowing and constructing select bodies of knowledge'. We propose that the following epistemological questions be asked through a trans-disciplinary discourse:

- What is our role in the development of a decolonised academic and praxis agenda?

- Where will we obtain our knowledge and understanding from?

- How do we include the African worldview in developing new knowledge and skills?

- How do we ensure a bottom-up approach to the development and implementation of academic material?

- How do we inform praxis in terms of Africanised and decolonised knowledge?

- How should we reposition ourselves? (cf. Morley \& Macfarlane 2010:48).

The exploration of these questions should become part of a journey that creates opportunities for daring and challenging 
thoughts about what we need to know and to find ways to obtain relevant, contextualised knowledge, understanding and skills. The willingness to enter into a process of challenging existing knowledge and praxis is one step towards transformation (Dumbrill \& Green 2008:499). Contextualising with the aim to Africanise curricula requires that we develop our knowledge, understanding and skills based on an exploration of the '... life experiences, history and traditions of African people as the centre of analyses' (Thabede 2008:234). We specifically acknowledged that the contextualising of academic work includes an understanding that all contexts are exposed to dynamic socio-economic and political processes and that knowledge and understanding are therefore not static.

Principles to include when contextualising the African worldview include the interconnectedness of all things; the spiritual nature of human beings; collective and individual identity; the collective/inclusive nature of family structure; the oneness of mind; body and spirit; and the value of interpersonal relationships (Thabede 2008:238). MeckledGarcia (2011:5) draws a link between interpersonal relationships between different groups in a diverse society and social justice in praxis. In the case of efforts to work towards a decolonised and Africanised curriculum, social justice as a part of interpersonal relationships means that the aforementioned efforts should be based on the moral values associated with social justice, including fairness, equality, worthiness and rights and responsibilities applicable to all (Meckled-Garcia 2011:5). These values emphasise the recognition of context, while social justice requires more. Social justice requires consideration of equity and people's different capabilities (cf. Sen 1999; Taylor 2011). The acknowledgement of the viewpoints of the South African people relates to principles such as self-determination, participation and collaboration that characterise the community development approach. In a post-colonial context, it means that we need to move towards hope and an aspiration to live our lives in an African manner, while also dreaming of developing our own knowledge, understanding and skills to contribute to the continent and the global agenda of community and social well-being (Tamburro 2013:4-5).

\section{Developing communities as an outcome of Africanisation}

In this section, we argue that professional carers should be educated and trained to practice their professions in a culturally aware and sensitive manner. Students must therefore be equipped with a '... working knowledge and understanding of their clients' social and cultural attachments' (Green \& Baldry 2008:391-392).

The influences of colonialism and the post-colonial era firstly point to external facets that influence the current socioeconomic functioning of the South African people. Past and present socio-economic and political trends represent external facets that dominate communities' well-being. This then leads to internal facets that prevent communities to decolonise their minds and to develop ownership for their own lives and futures. Internal facets include stagnation (an attitude of 'this is as good as it gets'), disempowering emotions, a lack of participation and excessive conflict situations (Weyers 2011:39). Africanisation of academic material to inform praxis implies that academia (as an external facet) facilitates a process where internal facets are being addressed. Dumbrill and Green (2008:499) concur that the use of indigenous knowledge systems to inform academic curricula should result in creating a space where the people of the country find hope for a better future. In support of this statement, Villanueva (2013:25) notes that '... to devote a space only for critiques without offering hope is to ensure despair'.

The above description of Africanisation as part of developing a decolonised curriculum highlights the importance of obtaining our Africanised knowledge, understanding and skills from grassroots level. This points towards community involvement and participation and therefore to the characteristics of the community development approach. Confirming this viewpoint, Weyers (2011:39) asserts that community development aims to facilitate partnerships between local people and external systems (e.g. academia) to improve material (e.g. educational infrastructure) and nonmaterial (e.g. social, cultural, economic and political) facets of community life. The goals of community development include the following:

- Stimulating interest in an effort to encourage participation.

- Promoting unity.

- Acknowledging negative or painful emotions, attitudes and behaviours and to explore the origins thereof.

- Creating opportunities to explore African ways of dealing with problems.

- Identifying knowledge, understanding and skills that could address societal problems.

These goals are ultimately aimed at creating a community identity, vision and hope (Weyers 2011:40).

In terms of the academic knowledge base of the caring professions, the community development approach provides us with a framework from which we could work towards participation by and empowerment of the South African people at grassroots level. Therefore, it is important that participation should be outcome based and lead to empowerment as an outcome. Participation should ensure that people be part of decision making and the implementation thereof. The aim is to ensure that social justice becomes a reality and not a 'term' or a dream. This approach specifically requires that we engage with people on grassroots level and that these engagements inform praxis. It also requires that academia should disseminate research findings that reflect the voices of the people of South Africa. In addition, this knowledge should inform the 'how' and 'what' we teach students in the caring professions.

However, it should be noted that various research studies provide us with a vast knowledge base regarding the 
viewpoints of South African people (cf. Borum 2006; Bozalek 2011; De Gruchy \& Ellis 2008; Hart 2012; Le Bruyns \& Pauw 2004; Swart 2006; Thabede 2008; Van der Westhuizen \& Greuel 2016; Wielenga 2013). On the one hand, we come to understand that we did make a move towards the Africanisation of our knowledge base and therefore towards decolonisation. On the other hand, the South African people become more and more vocal about their frustrations of not being heard. Examples of violent protests are rife and the dissatisfaction of people also reflects on how we disseminate the knowledge that we gained. This then means that the knowledge derived from research does not reach those who develop policies and plan services. The need to find ways to ensure that bottomup research informs praxis (including education and training and policy development).

This discussion will be concluded with some strategic options on how community development can become a guiding principle of the development and implementation of Africanised curricula with a specific aim to inform praxis so as to ensure that the South African people benefit.

\section{Strategic options}

This trans-disciplinary discussion placed the emphasis on working from a community development approach when developing Africanised and decolonised academic curricula. The strategic options that we present is based on an adaptation of Thabede's (2008:234) suggestions for the development of an Afrocentric perspective to inform academia and praxis, namely:

- We need to acknowledge that African cultural knowledge is essential to effectively address the psychological, intellectual, spiritual and emotional needs of African people.

- Members of the trans-disciplinary team must become energised by the prospect of understanding phenomena from the viewpoint of Africans themselves.

- Space must be created to obtain data to develop African culture-based theories that will inform academic content and praxis.

- A contribution can be made on national and international level if Afrocentric perspectives are included as a significant part of the knowledge base and praxis alongside current Eurocentric intervention theories and praxis.

The trans-disciplinary framework requires, on the one hand, that we include the South African people when we identify the content needed to develop Africanised curricula. On the other hand, it emphasises that Africanised theories should lead to praxis that improves the lives of the African people. This means that we need to base our knowledge, understanding and skills on indigenous knowledge systems to contextualise our understanding of how to contribute to a just African society. We will discuss participatory research and narrative inquiry as two options to utilise when developing Africanised curricula. In addition, we will discuss how Africanisation can become part of the education and training of students in the professional caring professions.

\section{Participatory research}

Participatory research, as a method to obtain information to build a contextualised knowledge base focuses on social investigation, education and action that are aimed at the improvement of the participants' lives. By including the South African people in the composition of academic curricula, we not only decolonise academia but also provide the participants to '.. . begin to view their situations from alternative perspectives' (Bozalek 2011:472-474). Guijt (2014:2) identifies two underlying facets of participatory research that relate to both the community development approach and the principles to include when contextualising information. On a pragmatic level, the inclusion and participation of a variety of key role players results in a wealth of data that represent the 'insiders' in the situation, which leads to a better understanding and more appropriate application of obtained knowledge to ensure empowerment. Another facet is ethical practice. By acknowledging the right to participation by people who are directly or indirectly affected by the research topic, a rights-based approach is followed, which aligns with the community development approach and moral values of social justice.

Participatory research involves the trans-disciplinary team and '... those people whose life-world and meaningful actions are under study' (Bergold \& Thomas 2012:2). It results in a multiperspective investigation of a specific context. Expanding on this description, Chevalier and Buckles (2013:3) assert that participatory research engages a variety of disciplines (i.e. trans-disciplinary), theoretical perspectives (i.e. existing knowledge base) and stakeholders (i.e. the people on grassroots level). It is a purposeful engagement to mobilise the discovery of new evidence to inform theory building and praxis. In order to obtain a true understanding of the viewpoints of the South African people, we propose this strategy based on the following description by Bergold and Thomas (2012):

In the best case, both sides benefit from the research process. Everyday praxis, which have long since established themselves as a subject of inquiry, introduce their own perspective, namely, the way people deal with the existential challenges of everyday life. The participatory research process enables co-researchers to step back cognitively from familiar routines, forms of interaction, and power relationships in order to fundamentally question and rethink established interpretations of situations and strategies. (p. 2)

Bergold and Thomas (2012:5-14) advise that participatory research should firstly include democracy, including all role players and different capabilities, as a precondition. The inclusion of all the people inside of the situation and/ or associated with the situation is essential to be able to claim that one has a true understanding and empirical findings that contribute to theory. Secondly, the past hurt and social injustices that informed the colonised eras must be acknowledged. This means that sensitivity for the nature of disclosures is needed. Safe spaces to share viewpoints and experiences are therefore key to the process of participatory research. Lastly, the importance of reflection is highlighted: 
In participatory research, all participants are involved as knowing subjects who bring their perspectives into the knowledge-production process. (Bergold \& Thomas 2012:14)

The sharing of personal information provides the participants with an opportunity to express themselves, while also reflecting on the reasons behind their thoughts, feelings and actions. The information also affects the researchers (i.e. trans-disciplinary team), who have to reflect on how this information influences their current understanding of the research topic.

Participatory research makes use of both the quantitative and qualitative research approaches. Based on the above discussion and the emphasis to include the African worldview to develop Africanised and decolonised curricula, we support the use of the qualitative research approach. One method to collect data is narrative inquiry, which will be discussed next.

\section{Narrative inquiry}

Narrative inquiry is a data collection method associated with the qualitative research approach. It refers to an interpretive way of thinking and involves data obtained from words, pictures, descriptions or stories (Grinnell \& Unrau 2008:413). Through a purposeful inquiry of the real-life stories of South African people, a holistic picture of experiences, viewpoints, motives and behaviour can be obtained (Borum 2006:342). When developing curricula, we need to ensure that content is based on empirical evidence. Africanisation of content can thus be supported by narrative inquiry because the participants' life experiences would be best understood from the exploration of their own stories (Schwandt 2007:22), while also ensuring ethical practice as it increases collaboration and participation.

Storytelling, as an interpretative approach to narrative inquiry, can contribute to the body of knowledge for Africanised academic work. This also includes music, dance and photography as methods to address language barriers and to contribute to a non-threatening space for sharing stories. In line with the description of the community development approach, Mitchell and Egudo (2003:1) explain that '... the story becomes an object of study, focusing on how individuals or groups make sense of events and actions in their lives'. Lederach and Maiese (2009:7-8) assert that narrative inquiry in the form of storytelling serves as a strategy where members of a community not only reflect on the painful past and present challenges, but where they are afforded an opportunity to develop a vision for a better future as follows:

... individuals and a nation repeat stories to one another in an attempt to bring coherence to past events and to make sense of the present and the future. (cf. Bozalek 2011:472)

This description points to a potential value of the process of obtaining evidence-based material for Africanised curricula, namely social transformation that is being stimulated in the process. In terms of using discourses to obtain the stories, Creswell (2006:55) mentions that it begins with the experiences as expressed in lived and told stories of individuals. Creswell (2006:55-57) proposes the following process when making use of storytelling to obtain empirical data:

1. The choice of the topics of stories to be explored must relate to what we need to know.

2. We need to make sure that all the relevant stakeholders are included in opportunities to provide detailed stories of life experiences.

3. Information about the context of these stories must be collected.

4. The stories must be analysed, and then we must '... restory them into a framework that makes sense' to be included in academic material.

In order to acknowledge that students in the South African tertiary educational system are also South African citizens, we need to not only obtain knowledge to inform the content of the academic material presented to the students but also inform how we will present the material (cf. Abdi 2006:17). Therefore, students must be included in our efforts to Africanise and contextualise academic content.

\section{Africanisation in the classroom}

Crampton (2015:4) asserts that there is often a disconnectedness between what we learn in the classroom and praxis. Africanisation of academic material is specifically aimed at enabling students to use contextualised theories to become able to engage in best-practice work. Villanueva (2013:25-37) refers to the decolonisation of the classroom to empower students to develop their own understanding of the African context and to become able to deliver culturally sensitive services. This entails a strong emphasis on challenging the relevance of existing material (i.e. Western theories) in the African context, responding to evidence-based identified needs of the communities we serve and working towards social justice. The author furthermore proposes a trans-disciplinary framework from which curricula are developed and presented to students.

Students should be viewed as members of an unequal South African community who also need healing. Therefore, similar to the beneficiaries and other role players, students should have the opportunity to express themselves, while also reflecting on the reasons behind their thoughts, feelings and actions. In this way, students are exposed to learning processes that ensure the development of knowledge and skills related to the implementation of social justice. Working within the community development framework, we therefore also have to include the voices of students when developing Africanised curricula, as well as when we present the content to them. In this regard, Razack (2009:10) proposes the following:

- That we engage them in participatory research processes (thereby teaching them to 'hear' the communities we serve). 
- That they participate in narratives in the classroom to develop cultural sensitivity.

- That we include activities in the classroom aimed at developing the ability to function within a multicultural context while solving problems for the greater good.

\section{Conclusion}

Decolonising academia entails the development of an understanding of the real-life meaning South African citizens attach to their contexts. Therefore, we argue that a collaboration of a bottom-up trans-disciplinary approach to Africanisation, Western perspectives and contextualisation are key to the development of curricula that will empower students, include them in exploring solutions for societal problems (i.e. participation, collaboration and cooperation) and guide them to become effective facilitators of community development.

Research should support the Africanisation of academic material, so as to ensure a high-quality, scientifically sound knowledge and skills base. Over the past 22 years, South African academics and researchers contributed to a vast number of qualitative research studies that should, presumably, have affected the Africanisation of curricula and praxis. However, based on the growing voiced dissatisfaction of the South African people regarding their socio-economic situations, the following questions now arise:

- Are the African context-based research findings in fact included in the academic material presented to students?

- Are the findings disseminated in such a way that it informs praxis?

- Are the findings disseminated in such a way that it results in trans-disciplinary discourses and the development of a trans-disciplinary knowledge and skills base?

- Does Academia influence policy making and implementing processes effectively?

We argue that, for decolonisation to become real, socioeconomic transformation and social justice should be evident in our communities. In conclusion, we need to reflect on what Africanised knowledge and skills are available, what knowledge and skills are needed and how we can obtain such knowledge and skills and then actively engage in a process to inform transformative work.

\section{Acknowledgements Competing interests}

The authors declare that they have no financial or personal relationships which may have inappropriately influenced them in writing this article.

\section{Authors' contributions}

M.v.d.W. and T.G. conducted research that informed this study. The article is not a report of the research findings, but of how the research informed our trans-disciplinary understanding of Africanised and contextualised curricula that inform decolonisation and support praxis. By means of trans-disciplinary discourse and work, the findings of the research have been utilised to inform academic content that was developed by all three authors, namely; M.v.d.W., T.G. and J.W.B. The strategic options discussed in this article therefore emanated from both the research findings and the development of academic content.

\section{References}

Abdi, A.A., 2006, 'Eurocentric discourses and African Philosophies and epistemologies of education: Counter-hegemonic analyses and responses', International Education Fall Edition, 15-31.

Association of South African Social Work Education Institutions (ASASWEI), 2016 Decolonising social work education in South Africa, A report emerging from a series of workshops held in September 2016, Draft 2, 18 October 2016, Association of South African Social Work Education Institutions, Johannesburg.

August, K.T., 1999, 'A curriculum for community development in Practical Theology', Unpublished MPA thesis, University of Stellenbosch, Stellenbosch.

Bergold, J. \& Thomas, S., 2012, 'Participatory research methods: A methodological approach in motion', Forum Qualitative Sozialforschung/Forum: Qualitative Socia Research 1(30), 1-31.

Beukes, J.W., 2016, 'Belhar en 'n Teologie van Ontwikkeling in 'n Konteks van Armoede en Ongeregtigheid', Sun Media, Stellenbosch.

Borum, V., 2006, 'Reading and writing womanist poetic prose - African American mothers with deaf daughters', Qualitative Inquiry 12(2), 340-352. https://doi. org $/ 10.1177 / 1077800405284376$

Botman, H.R., 2004, 'Human dignity and economic globalization', Nederduitse Gereformeerde Teologiese Tydskrif 45(2), 317-327.

Bozalek, V., 2011, 'Acknowledging privilege through encounters with difference: Participatory learning and action techniques for decolonising methodologies in Southern contexts', International Journal of Social Research Methodology 14(6), 469-484. https://doi.org/10.1080/13645579.2011.611383

Chevalier, J.M. \& Buckles, D.J., 2013, Handbook for participatory and action research, planning and evaluation, SAS2 Dialogue, Ottawa.

Crampton, A., 2015, 'Decolonizing social work "Best Praxiss" through a philosophy of impermanence', Journal of Indigenous Social Development 4(1), 1-11.

Creswell, J.W., 2006, Research design, qualitative, quantitative, and mixed methods approaches, 2nd edn., Sage, Los Angeles, CA.

De Gruchy, S., 2003, 'Of agency, assets and appreciation: Seeking some commonalities between theology and development', Journal of Theology for Southern Africa 117, 20-39.

De Gruchy, S. \& Ellis, W., 2008, 'Christian leadership in another country: Contributing to an ethical development agenda in South Africa', in S. De Gruchy, N. Koopman \& S. Strijbos (eds.), From our side: Emerging perspectives in development and ethics, pp. 9-20, Brill, Leiden.

Dumbrill, G.C. \& Green, J., 2008, 'Indigenous knowledge in the social work academy', Social Work Education 27(5), 489-503. https://doi.org/10.1080/02615470701379891

Geoghegan, M. \& Powell, F., 2006, 'Community development, partnership governance and dilemmas of professionalisation: Profiling and assessing the case of Ireland', British Journal of Social Work 36, 846-861. https://doi. org $/ 10.1093 / \mathrm{bjsw} / \mathrm{bch} 344$

George, J., 2012, 'Intercultural theology: An approach to theologizing in the context of Pluralism and globalization', Unpublished Master of Theology Degree Thesis, Toronto School of Theology, Toronto.

Green, S. \& Baldry, E., 2008, 'Building indigenous Australian social work', Australian Social Work 61(4), 389-402. https://doi.org/10.1080/03124070802430718

Grinnell, R.M. \& Unrau, Y.A., 2008, Social work research and evaluation: Foundations of evidence-based praxis, Oxford University Press, New York.

Guijt, I., 2014, Participatory approaches: Methodological briefs - Impact evaluation no. 5, UNICEF Office of Research, Florence, Italy.

Hart, C.S., 2012, 'Professionalisation of community development in South Africa: Process, issues and achievements', Africanus 42(2), 55-66.

Kinnunen, K. \& Kaminski, W., 2003, Enhancing cultural awareness through cultural production, Kauniainen Unit of Humanities Polytechnic and the Korpilahti Unit of Humanities Polytechnic \& University of Applied Sciences, Cologne.

Koegelenberg, R.A. (ed.), 1992, Church and development: An interdisciplinary approach, EFSA, Bellville.

Le Bruyns, C. \& Pauw, C., 2004, 'Looking in two ways: Poverty in South Africa and its ecclesiological implications', Nederduitse Gereformeerde Teologiese Tydskrif 45(2), 202-213.

Lederach, J. \& Maiese, M., 2009, 'Conflict transformation: A circular journey with a purpose', New Routes 14(2), 7-11.

Le Grange, L., 2014, 'Currere's active force and the Africanisation of the university curriculum', South African Journal of Higher Education 28(4), 1283-1294.

Meckled-Garcia, S., 2011, Human rights or social justice? Rescuing human rights from the outcomes view: Working Paper 30, School of Public Policy, University College, London. 
Mitchell, M. \& Egudo, M., 2003, A review of narrative methodology, Land Operations Division: Systems Sciences Laboratory, Government of Australia, Edinburgh, South Division: Syst
Australia.

Morley, C. \& Macfarlane, S.M., 2010, 'Repositioning social work in mental health Challenges and opportunities for critical praxis', Critical Social Work 11(2), 46-59.

Nicolescu, B., 2005, Towards transdisciplinary education and learning, paper prepared for Conference on Science and Religion: Global Perspectives, Metanexus Institute, Philadelphia, PA, 4-8 June.

Nissani, M., 1995, 'Fruit salads and smoothies: A working definition on interdisciplinarity', Journal of Educational Thought 29, 121.

Nürnberger, K., 1994, 'The task of the church concerning the economy in a postapartheid South Africa', Missionalia 22(2), 118-146.

Prinsloo, E.H., 2016, 'The role of the humanities in decolonising the academy', Arts \& Humanities in Higher Education 15(1), 164-168. https://doi.org/10.1177/ 1474022215613608

Razack, N., 2009, 'Decolonizing the pedagogy and praxis of international social work', International Social Work 52(1), 9-21. https://doi.org/10.1177/0020872808097748

Schwandt, T.A., 2007, The dictionary of qualitative research, 3rd edn., Sage, Thousand Oaks, CA.

Sen, A., 1999, Development as freedom, Oxford University Press, Oxford.

Stock, P. \& Burton, J.F., 2011, 'Defining terms for integrated (multi-inter-transdisciplinary) sustainability research', Sustainability 3, 1090-1113. https://doi. org/10.3390/su3081090

Swart, I., 2006, 'Transforming social welfare? The religious discourse on social development in post-apartheid South Africa', paper presented at the First Conference of the South-African Swedish-Research Links Project, Welfare and Religion in a Global Perspective: Theoretical and Methodological Exchange Across Religion in a Global Perspective: Theoretical and Methodological
Tamburro, A., 2013, 'Including decolonization in social work education and praxis', Journal of Indigenous Social Development 2(1), 1-16.

Taylor, V., 2011, A question of social justice: A social minimum for protection and inclusion, International Policy Analysis, Friedrich-Ebert-Stiftung, Berlin, viewed 17 December 2016, from http://library.fes.de/pdf-files/iez/0835020110803.pdf

Thabede, D., 2008, 'The African worldview as the basis of praxis in the helping professions', Social Work/Maatskaplike Werk 44(3), 233-245.

Thesnaar, C.H., 2012, 'A pastoral hermeneutical approach to reconciliation and healing: A South African perspective', in M. Leiner \& S. Fläming (ed.), Latin America between conflict and reconciliation, pp. 215-229, Van den Hoeck \& Ruprecht, Göttingen.

Van der Westhuizen, M.A. \& Greuel, T., 2016, Leading intercultural musical projects to create a 'sense of community': A community development approach, Unpublished research document, Hugenote Kollege and Evangelische Hochschule RheinlandWestfalen Lippe, Wellington, South Africa.

Van der Westhuizen, M.A. \& Kleintjes, L., 2015, 'Social work services to victims of xenophobia', The Social Work Practitioner-Researcher 51(1), 115-134. https://doi. org/10.15270/51-1-431

Velthuizen, A., 2012, 'A transdisciplinary approach to understanding the causes of wicked problems such as the violent conflict in Rwanda', The Journal for Transdisciplinary Research in Southern Africa 8(1), 51-62. https://doi.org/ 10.4102/td.v8i1.5

Villanueva, S.T., 2013, 'Teaching as a healing craft: Decolonizing the classroom and creating spaces of hopeful resistance through chicano-indigenous pedagogical praxis', Urban Review 45, 23-40. https://doi.org/10.1007/s11256-012-0222-5

Weyers, M.L., 2011, The theory and praxis of community work: A South African perspective, Xerox, PU for CHE, Potchefstroom.

Wielenga, C., 2013, 'Shattered stories: Healing and reconciliation in the South African context', Verbum et Ecclesia 34(1), 1-14. https://doi.org/10.4102/ve.v34i1.747 